\title{
The Impact of Perceived Leadership Style on Performance Appraisal Satisfaction and Organizational Diagnosis in terms of Turnover Intention
}

\author{
İzlem Gözükara ${ }^{1}$, Zeynep Hatipoğlu ${ }^{2} \&$ Özlem Öncel Güneş ${ }^{3}$ \\ ${ }^{1}$ Department of Business Administration, Istanbul Arel University, İstanbul, Turkey \\ ${ }^{2}$ Department of Business, Nişantaşı University, İstanbul, Turkey \\ ${ }^{3}$ The Institute for Graduate Studies, Maltepe University, Istanbul, Turkey \\ Correspondence: İzlem Gözükara, Istanbul Arel University, Türkoba Mahallesi Erguvan Sokak No:26 / K \\ 34537, Tepekent - Büyükçekmece, İstanbul,Turkey. E-mail: izlemg@arel.edu.tr
}

Received: June 29, 2017

doi:10.5539/ijbm.v12n9p104
Accepted: August 7, 2017

Online Published: August 12, 2017

URL: https://doi.org/10.5539/ijbm.v12n9p104

\begin{abstract}
The present paper aimed to examine the extent to which the leadership style perceived by employees affects organizational development and employees' satisfaction with performance appraisal system and turnover intention between such relationships. For this purpose, this study utilized a descriptive survey method and collected data using questionnaires. The study sample included 245 participants. The data were analyzed using structural equation modeling. Results demonstrated that perceived leadership style has a positive effect on both organizational diagnosis and performance appraisal satisfaction, while turnover intention is only negatively affected by performance appraisal satisfaction.
\end{abstract}

Keywords: organizational diagnosis, performance appraisal satisfaction, perceived leadership style, turnover intention

\section{Introduction}

Survival and sustainability are the major concerns of organizations nowadays. In order to achieve a sustained success, organizations have to be aware of the changing conditions and able to respond accordingly. Although this fact renders change inevitable, organizational change can be a very challenging process. Such process cannot be achieved without leaders as it is well established that leaders play a key role in organizational change and development (e.g. Deal \& Kennedy, 2000). Leadership is a crucial concept for organizations in many aspects. Among others, leaders have an impact on employee attitudes, which has the potential to create changes in employees' future behaviors. The literature presents numerous types of leadership; however, the last two decades of research seem to focus especially on transformational and transactional leadership styles that are a part of the Full Range Leadership Theory (Bass \& Avolio, 1997). Particularly associated with positive change both at individual and organizational levels, transformational leaders modify employees' beliefs, values and interests, motivating them to show a beyond-expectation performance (Pieterse et al., 2010). Transactional leadership, in turn, motivates employees using an exchange process that offers rewards depending on accomplishment. The third style of the Full Range Theory, laissez-faire leadership is known as non-leadership, indicating passive leadership behaviors (Yukl, 2002).

To implement a change in an organization, a leader has to identify organizational issues. For this purpose, several diagnostic tools have been developed. Organizational diagnosis stimulates the development of an organization and induces change for sustainability (Koziol et al., 2015). Therefore, models of organizational diagnosis have been widely used by the organizations in collecting data regarding their whole system, sections, processes and cultural aspects (French et al., 2006). One of the striking models is the Weisbord's (1976) six-box model, which focuses on internal management, offers a well-established guideline for establishing the internal factors that should be acquired by the individuals or the organization for developing a strategy toward organizational change.

Another role of leaders is to evaluate the performance of their followers. Performance appraisal systems aim to facilitate and improve the development of employees, and remove the barriers to performance (Dusterhoff et al., 
2014). Both employees and employers benefit from performance appraisal in terms of identifying, conveying and modifying their goals, expectations and advancement toward goal accomplishment (Bacal, 2004). Accordingly, employee reactions to performance appraisal systems are recognized as one of the basic criteria used to assess the applicability of the respective system (Boachie-Mensah \& Seidou, 2012). Despite the fact that the efficacy of such systems depends on the employee perception of their fairness and equity (Keeping \& Levy, 2000), the attention to the employee reaction for performance appraisal systems has remained scarce (Kuvaas, 2011).

For better performance and sustainability, organizations and leaders have to retain their topmost performing employees because employee turnover creates serious costs for organizations (Arshadi \& Shahbazi, 2013). Thus, employees' intent to quit has become important as it enables organizations to take necessary measures and avoid future resignations. Leadership, again, is one of the factors decreasing such impact of turnover intentions on organizations. Based on this theoretical background, the present study aims to investigate the extent to which transformational, transactional and laissez-faire leadership styles are associated with organizational diagnosis, performance appraisal satisfaction and turnover intention.

\section{Perceived Leadership Style}

Leadership defines a process which aims to accomplish shared goals by aiding both individual and collective goals and it includes influencing other people in order to establish the effective operation of organizational elements (Yukl, 2002). From the 1990s, a greater part of the research on leadership has been centered on transformational and transactional leadership styles. The concept of transformational and transactional leadership was first introduced by Burns (1978) to explain leader traits and further expanded by Bass (1985). In 1997, Bass and Avolio developed the Full-Range Leadership Theory (FLRT), which includes three leadership styles as transformational, transactional, and laissez-faire.

Transformational leadership covers certain behaviors; inspirational motivation, individualized influence, intellectual stimulation, and individualized consideration (Bass, 1985). Inspirational motivation refers to providing an explicit and inspirational vision of the organization and challenging followers to better their performance and for the achievement of the organizational goals (Paarlberg \& Lavigna, 2010). Individualized influence entails being a role model and earning followers' admiration and trust (Srithongrung, 2011). Intellectual stimulation involves inspiring followers to question the existing conditions and to improve problem-solving abilities by being creative (Pieterse et al., 2010). Individualized consideration refers to caring and paying individual attention to each follower through professional development, coaching, and mentoring (Nielsen \& Munir, 2009). Transformational leaders offer their followers inspiration to achieve high-level needs such as self-actualization, improvement and collective goals (Srithongrung, 2011). On the other hand, high-level needs cannot be induced under transformational leadership unless such goals are determined and rewards are granted (Rainey, 2009). This is why transformational leadership is considered a leadership relying on or expanding the approaches of transactional leadership (Oberfield, 2014).

Transactional leadership, in turn, involves a particular way of interaction with followers in order to determine how to achieve tasks and informing them about rewards based on their performance (Avolio et al., 1999). Transactional leadership is characterized by three particular behaviors. The first one, contingent reward, means that followers who complete their tasks beyond expectations are automatically rewarded. The second one, management by exception (active), means that followers are subject to monitoring and corrected when necessary for better performance. The last one, management by exception (passive), means that followers who perform their tasks inconsistent with the organizational goals are punished conditionally. Contrary to the transformational style, transactional leaders focus on motivation by means of an exchange process in which followers are granted rewards based on their accomplishment of pre-established targets for performance. Such exchange process makes transactional leadership address only to low-level needs such as security and salary. Therefore, transactional leadership exerts a much smaller effect on favorable outcomes compared to transformational leadership that utilizes intrinsic motivation (Bass \& Riggio, 2006).

The laissez-faire dimension of the theory is usually considered as non-leadership in which such leaders do not concern or act when the organization encounters with important issues. The laissez-faire leadership refers to the non-existence of or refrainment from leadership (Judge \& Piccolo, 2004). Bass and Avolio (1997) described laissez-faire leadership as the absence of an actual leadership, which makes it an ineffective and inactive style as shown by leadership research. Accordingly, this leadership style is recognized as the most passive and unproductive leadership style (Yukl, 2002). Laissez-faire leaders are likely to abstain from all their responsibilities and supervising the organization. Such leaders are passive and are not interested in the needs and 
problems of their followers. Additionally, such leaders do not make necessary decisions on time for problem solving (Limsila \& Ogunlana, 2008). Laissez-faire leaders refrain from leading, and they are not interested in supporting or improving either their followers or organization.

\section{Organizational Diagnosis}

Organizational diagnosis is a systematic way of identifying organizational issues, collecting and analyzing data and reaching a conclusion through the findings in order to realize necessary changes. Accordingly, organizational diagnosis refers to a group process involving the presence of common and similar approaches. Organizational diagnosis does not only concern about problem elimination, but it also requires realizing changes and adopting new directions. With such changes, the future performance is likely to enhance and the organization is likely to develop to a greater extent (Cummings, 2005).

The literature presents several models for organizational diagnosis. Among these, the Weisbord's (1976) six-box model distinguishes from many other diagnostic models as it is relatively broader with its six categories. The Six-Box Model of Weisbord (1976) contains six categories for an organizational diagnosis: purpose, structure, relationships, rewards, leadership and helpful mechanisms. According to the model, purpose, similar to mission, refers to the business of the organization. The purpose of an organization should be straightforward for all organizational members and it should be followed even when the members do not agree with it or have different opinions about it; meaning that the same determined purpose should be pursued by the entire organization. Structure refers to the work division within an organization, which describes the formal relationships between the functional levels of an organization. The structure of an organization should present an applicable and actual depiction of the legal power and it is considered a formal approach of facilitation toward the achievement of organizational purpose. Relationships refer to conflict management within an organization, including individuals, groups, technology, and other functional divisions. Rewards are about the presence or absence of incentives in order to accomplish tasks. The last category, helpful mechanisms, refers to the approaches of activity coordination. Such mechanisms may include the definition of organizational strategies, seminars or reports that are formulated to build favorable relations between organizational divisions.

Briefly, there are two basic propositions underlying the six-box model. First is the relationship between formal systems and informal systems. The formal system refers to written rules and procedures, while informal systems encompass organizational behaviors. In other words, informal systems represent the conditions that organizational members follow such rules and procedures. The balance of these two systems is reached through a successful management. The lack of such balance usually results in organizational inefficiency. The second proposition reflects the balance between the organization and the outside environment.

\section{Performance Appraisal Satisfaction}

Performance appraisal aims to assess, manage and ultimately improves the performance of employees. It is one of the most important practices of human resources (Boswell \& Boudreau, 2000). Appraisal systems are beneficial not just because they provide detailed information on employee performance, but because they also foster employees' attitudes and skills, leading to greater efficiency (Boswell \& Boudreau, 2002). The degree to which employees perceive that the performance rating system represents the behaviors which contribute to the organization is known as performance appraisal satisfaction" (Giles \& Mossholder, 1990), and usually deemed the most significant construct to assess employee reactions to the appraisal systems (Giles \& Mossholder, 1990; Levy \& Williams, 2004). Therefore, performance appraisal satisfaction has been a common measure of appraisal reactions (Keeping \& Levy, 2000), leading to extensive research regarding the elements with influence on satisfaction with performance appraisal; however, empirical evidence is yet to be established about the extent and reason of its significance.

Only a performance appraisal system that is considered fair produces favorable reactions from appraises and appraisers (Brown \& Benson, 2005). In this regard, Folger et al. (1992) suggested a performance appraisal model with three essential factors for increasing fairness perceptions of the appraisal system: adequate notice, fair hearing and judgement based on evidence. According to the model, adequate notice means informing employees about the performance appraisal system and its effects prior to the implementation of any formal appraisal. In other words, adequate notice requires establishing some guidelines and goals for performance before appraisal. Such guidelines and goals have to be clearly explained, understood and documented, and are preferably agreed upon mutually. By this way, employees would be responsible for only those of which they are informed. Another aspect of adequate notice is to perform appraisal on a frequent basis with regular feedback by the end of each assessment period in order to provide employees with the chance to improve any deficiencies (Folger et al., 1992). According to prior research, adequate notice is an important construct for the procedural fairness 
perceptions of employees. Fair hearing reflects several aspects in the context of a performance appraisal. Such aspects include the opportunity to affect the decision of appraisal based on argument and evidence, attain and object to the appraisal decision (Folger et al. 1992). Fair hearing involves bilateral communication, meaning that employees are included in the entire decision-making process of appraisal. Judgment based on evidence refers to the documentation of issues related to performance with factual evidence instead of personal thoughts (Folger et al. 1992).

According to Huselid (1995), the relationship between performance appraisal and turnover should not be assessed just on an individual level as the decision of employees to leave or stay at their organization derives from their perception of the performance appraisal system. Therefore, a performance appraisal practice that is favorable is likely to positively influence the attitudes and behaviors of employees as well as the effectiveness of the organization (Cennamo \& Gardner, 2008). For instance, the capacity of performance appraisal to represent, measure and assess an employee's behavior (Sarita, 2012), teamwork and information-sharing skills and achievements (Kimiz, 2005) leads to greater performance and efficiency. On the other hand, all positive consequences of performance appraisal depend on how the employee perceives the overall appraisal practice (Benson et al., 2010). If employees perceive that they receive unfair treatment, their attitudes start changing, leading them to decide to leave that organization (Vigoda, 2003).

\section{Turnover Intention}

Turnover means rotating employees between organizations and jobs as well as employment and unemployment states; it reflects the circulation of labor (Abbasi \& Hollman, 2000). The notion of turnover was first introduced by Price (1977) and defined as "the ratio of the number of organizational members who have left during the period being considered divided by the average number of people in that organization during the period" (p.13). Turnover intention, in turn, represents the employee cognitions about a voluntary leave from the employing organization (Schyns et al., 2007). In other words, the possibility that an employee quits job prior to a date that is specified is called turnover intention (Hughes et al., 2010).

Turnover intentions of employees have been widely researched both from organizational and industrial aspects, as they have the potential to cause seriously negative impacts on organizations (Watrous et al., 2006). Moreover, intention to leave is considered one of the best factors used to predict employee turnover (Griffeth et al., 2000).

Turnover intention does not only have financially negative effects, but it also reduces morale among employees and requires modification in productivity and customer relations (Abbasi \& Hollman, 2000). Furthermore, organizational performance is also affected by turnover intentions (Watrous et al., 2006). Turnover intention does not qualify as an actual leave; however, many organizational benefits can be gained by examining turnover intentions. For example, organizations may use turnover intentions as a means to assess and revise their human resource management strategies, determine their members with an intention to quit (Moynihan \& Landuyt, 2008), improve or restructure the circumstances resulting in turnover (Harris et al., 2005) and minimize the costs incurred by actual turnover (Hughes et al., 2010). Therefore, authors such as Harris et al. (2005) argue that examining turnover intentions provides greater benefit compared to actual turnover.

One of the factors that can reduce the adverse influence of turnover intentions on organizations is leadership. In this regard, transformational leadership is suggested to decline employees' opinions of quitting as such leadership provides a clear understanding of the organizational mission and demonstrates how that mission is in accord with employees' own values and beliefs (Bono \& Judge, 2003). Furthermore, Bass and Riggio (2006) argue that transformational leaders build an emotional commitment between the organizational mission and employees, which leads to decreased turnover intentions. The individualized consideration aspect of transformational leaders may also be beneficial in reducing turnover intentions because employees with the belief "that their personal needs are being met through a leader's individualized attention and consideration will be less likely to leave the leader who is meeting these needs" (Hughes et al., 2010, p. 353).

In light of the above theoretical background, the present study formulates the following hypotheses:

$\boldsymbol{H}_{1}$ : Leadership style is positively related with organizational diagnosis.

$\boldsymbol{H}_{2}$ : Leadership style is positively related with performance appraisal satisfaction.

$\boldsymbol{H}_{3}$ : Organizational diagnosis is positively related with performance appraisal satisfaction.

$\boldsymbol{H}_{4}$ : Performance appraisal satisfaction is negatively related with turnover intention. 


\section{Method}

\subsection{Research Goal}

The objective of the present research is to examine the link between perceived leadership style, organizational diagnosis, performance appraisal satisfaction and turnover intention.

\subsection{Participants and Procedure}

For study purposes, the study questionnaire was distributed to 250 participants; however, five questionnaires were ignored as they have several missing parts, and all study analyses were conducted by using the questionnaires collected from245 participants (Table 1).

Table 1. Demographic characteristics of participants

\begin{tabular}{|c|c|c|c|}
\hline & & $\mathrm{n}$ & $\%$ \\
\hline \multirow[t]{2}{*}{ Gender } & Female & 116 & 47.3 \\
\hline & Male & 129 & $52.7 \%$ \\
\hline \multirow[t]{2}{*}{ Marital status } & Single & 112 & $45.7 \%$ \\
\hline & Married & 133 & $54.3 \%$ \\
\hline \multirow[t]{5}{*}{ Children } & No & 151 & $61.6 \%$ \\
\hline & 1 child & 61 & $24.9 \%$ \\
\hline & 2 children & 24 & $9.8 \%$ \\
\hline & 3 children & 8 & $3.3 \%$ \\
\hline & 4 and more children & 1 & $4 \%$ \\
\hline \multirow[t]{3}{*}{ Age } & $52-70$ & 7 & $2.9 \%$ \\
\hline & $37-51$ & 53 & $21.6 \%$ \\
\hline & $18-36$ & 185 & $75.5 \%$ \\
\hline \multirow[t]{7}{*}{ Education } & Elementary & 96 & $39.2 \%$ \\
\hline & Secondary & 50 & $20.4 \%$ \\
\hline & High School & 32 & $13.1 \%$ \\
\hline & Two-year degree & 5 & $2.0 \%$ \\
\hline & Four-year degree & 2 & $8 \%$ \\
\hline & M.Sc. & 59 & $24.1 \%$ \\
\hline & $\mathrm{PhD}$ & 1 & $4 \%$ \\
\hline \multirow[t]{6}{*}{ d6 } & 3-6 months & 5 & $2.0 \%$ \\
\hline & 7-11 months & 8 & $3.3 \%$ \\
\hline & $1-2$ years & 35 & $14.3 \%$ \\
\hline & $3-5$ years & 36 & $14.7 \%$ \\
\hline & $5-6$ years & 82 & $33.5 \%$ \\
\hline & $\geq 11$ years & 79 & $32.2 \%$ \\
\hline
\end{tabular}

The responses of the participants were analyzed and interpreted by using SPSS for Windows 22.00, and AMOS 22.0 software programs. Factor analyses were applied to the measurement instruments employed and the Cronbach's alpha values were calculated. The confirmatory factor analysis of four research instruments was individually conducted by using the AMOS program. The path analysis of the model created using structural equation modeling was formulated using AMOS software.

\subsection{Measures}

Perceived leadership was measured by using the Multifactor Leadership Questionnaire Form-5X Short (MLQ-5X) developed by Bass and Avolio (1997) based on the theory of Full Range Leadership. The instrument includes 36 items with 20 items measuring transformational leadership (inspirational motivation, intellectual stimulation and individual consideration), 12 items measuring transactional leadership (contingent reward, management-by-exception (active) and management-by-exception (passive)) and 4 items measuring laissez-faire leadership.

Organizational diagnosis was measured using the Six-Box Questionnaire developed by Weisbord (1976) as an organizational diagnostic tool. The instrument consists of 30 items and 6 dimensions (purpose, structure, relationships, rewards, leadership and helpful mechanisms). All dimensions are measured through 5 items. 
Performance appraisal satisfaction was measured using the 18-item Due Process Scale developed by Buehler (2006). The instrument includes three dimensions: adequate notice, fair hearing, and judgment based on evidence measured through 6 items.

Turnover intention was measured using the Turnover Intention Scale developed by Schwepker (2001). The scale consists of 6 items questioning employees' possibility of leaving their organization. All scales used in this study were responded on a 5-point Likert rating system.

\section{Analyses and Results}

\subsection{Confirmatory Factor Analysis}

To determine the significance of the measurement models, confirmatory factor analyses (CFA) were conducted by using AMOS 22.0 software program. The results showed that the models are significant. Afterwards, fit indices were used to assess the adequacy of the whole model.

\subsubsection{Multifactor Leadership Questionnaire}

The confirmatory factor analysis of the 36-item MLQ was conducted by using 19 items as 17 items had low factor loads, and the analysis revealed a three-factor structure (Figure 1).

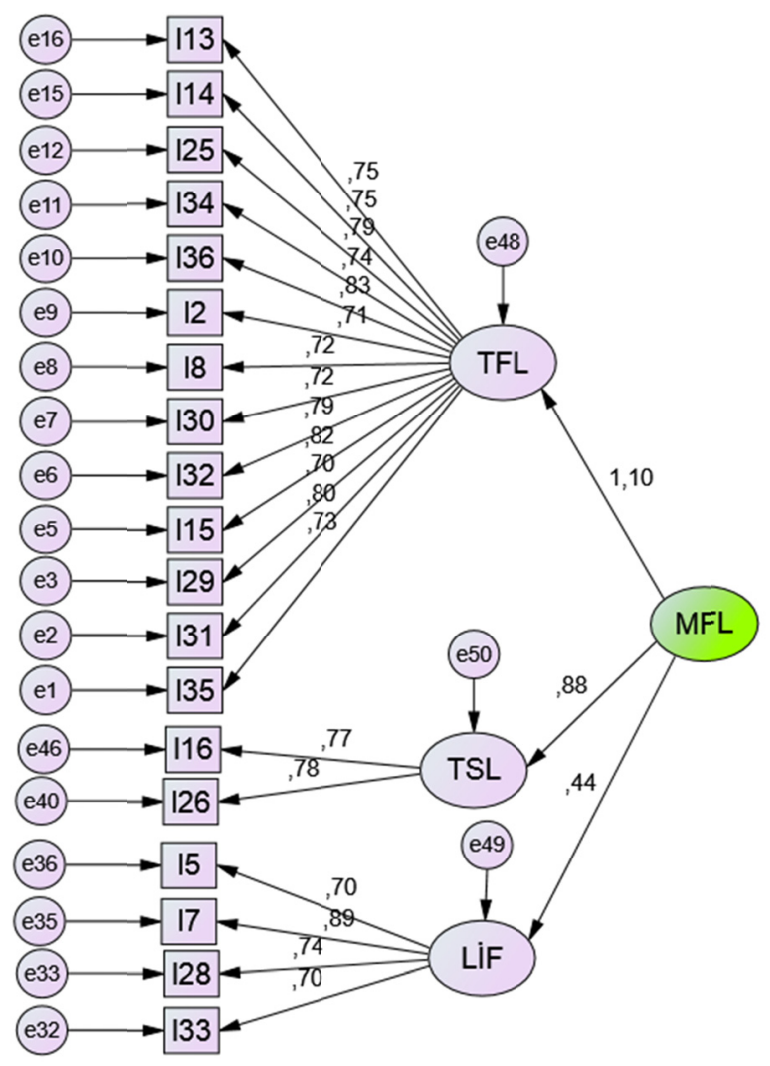

Figure 1. Multifactor Leadership Questionnaire's Confirmatory Factor Analysis

The model test values were $\mathrm{x} 2$ (290.632) and $\mathrm{x} 2 / \mathrm{df}$ (2.032), indicating that the MLQ confirmatory factor analysis was significant. As the goodness-of-fit indices [GFI (.890), CFI (.954) and RMSEA (.065)] were within the acceptable limits, the CFA result of MLQ was applicable.

\subsubsection{Organizational Diagnosis Scale}

In the factor analysis of the OLC scale, 7 items were removed from the analysis due to their factor loads $<40$. The analysis was completed with the remaining 23 items as a six-factor structure (Figure 2). 


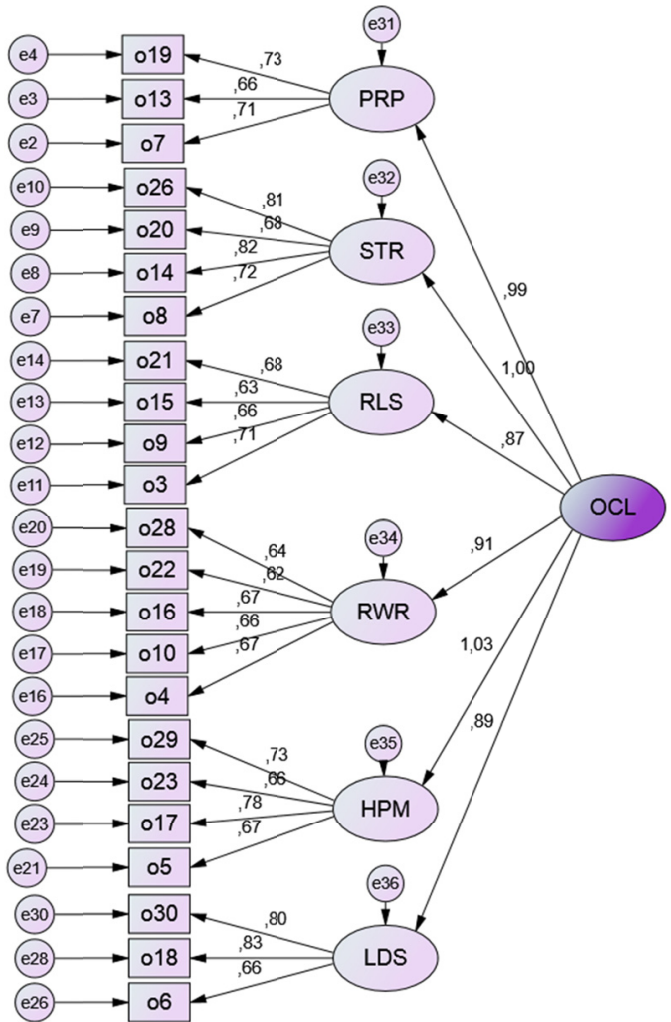

Figure 2. OD Scale's Confirmatory Factor Analysis

The model test values were $\mathrm{x} 2$ (372.337) and $\mathrm{x} 2 / \mathrm{df}(1.834)$, which indicated that the confirmatory factor analysis of the OLC scale was statistically significant. As the goodness-of-fit indices [GFI (.890), CFI (.951) and RMSEA (.058)] were within the acceptable limits, the CFA result of the OLC scale was applicable.

\subsubsection{Turnover Intention Scale}

The confirmatory factor analysis of the turnover intention scale included all 6 items. The goodness-of-fit indices for the single-factor structure are presented below (Figure 3).

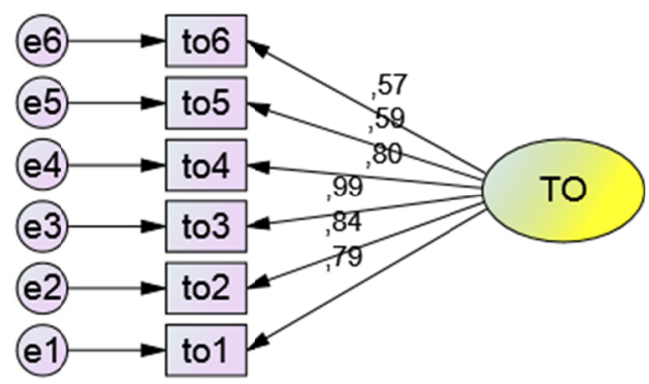

Figure 3. Turnover Intention CFA

The model test values were $\times 2$ (5.305) and $\times 2 / \mathrm{df}$ (1.061), which indicated that the confirmatory factor analysis of the turnover intention scale was statistically significant. As the goodness-of-fit indices [GFI (.993), CFI (.997) and RMSEA (.016)] were within the acceptable limits, the CFA result of the turnover intention was applicable.

\subsubsection{Performance Appraisal Satisfaction Scale}

The confirmatory factor analysis of the performance appraisal satisfaction scale included all 18 items and its three-factor structure was preserved. The findings from the factor analysis with 18 items are presented below 
(Figure 4).

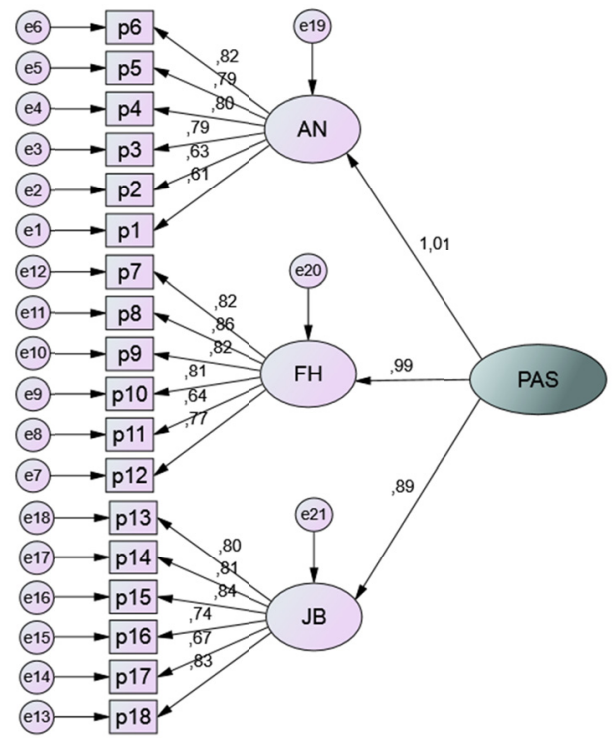

Figure 4. Performance appraisal satisfaction scale's confirmatory factor analysis

The model test values were $\mathrm{x} 2$ (291.642) and $\mathrm{x} 2 / \mathrm{df}$ (2.391), which indicated that the confirmatory factor analysis of the performance appraisal satisfaction scale was statistically significant. As the goodness-of-fit indices [GFI (.887), CFI (.952) and RMSEA (.075)] were within the acceptable limits, the CFA result of the performance appraisal satisfaction was applicable.

\subsection{Structural Equation Model - Path Analysis}

A path diagram was created by using the AMOS 22.0 software program to explore the hypothesized relationships, and the Maximum Likelihood method was used to estimate the structural parameters. The path diagrams of the model are shown in the respective figures. The AMOS structural equation analysis program provides results in the form of separate standardized and non-standardized coefficients. For better understanding, the present study employed the standardized coefficients.

The chi-square value calculated for fitness of the model in the structural equation modeling may produce incorrect decisions since it is affected by the sample size and the number of variables, and therefore, the decision is made based on the (x2/ df.) criterion instead of this value (e.g. Schermelleh-Engel et.al., 2003) (Table 2).

Table 2. Standard good fit indices and the fit indices calculated for the model

\begin{tabular}{llll}
\hline $\boldsymbol{n o}$ & Fit Indices & Good Fit & Acceptable Fit \\
\hline 1 & $\boldsymbol{x}^{2}$ & - & - \\
2 & $\mathbf{x}^{2} / \mathbf{s ~ d}$ & $\mathbf{0}<\mathrm{x}^{2} / \mathrm{d} \mathrm{f}<\mathbf{2}$ & $2<\mathrm{x}^{2} / \mathrm{s} \mathrm{d}<5$ \\
3 & RMSEA & $0<\mathrm{RMSEA}<0.05$ & $0.05<\mathrm{RMSEA}<0.08$ \\
4 & GFI & $0.95<\mathrm{GFI}<1.00$ & $0.90<\mathrm{GFI}<0.95$ \\
5 & CFI & $0.97<\mathrm{CFI}<1.00$ & $0.95<\mathrm{CFI}<0.97$ \\
6 & NFI & $0.95<\mathrm{NFI}<1.00$ & $0.90<\mathrm{NFI}<0.95$ \\
7 & SRMR & $0<\mathrm{SRMR}<0.05$ & $0.05<\mathrm{SRMR}<0.10$ \\
\hline
\end{tabular}

It is ascertained from the model that leadership style has a positive effect on organizational diagnosis (.56), organizational diagnosis positively affects performance appraisal satisfaction (.40), and leadership style has a positive effect on performance appraisal satisfaction (.49). Turnover intention, in turn, is negatively affected by performance appraisal satisfaction (-.31) (Figure 5). 


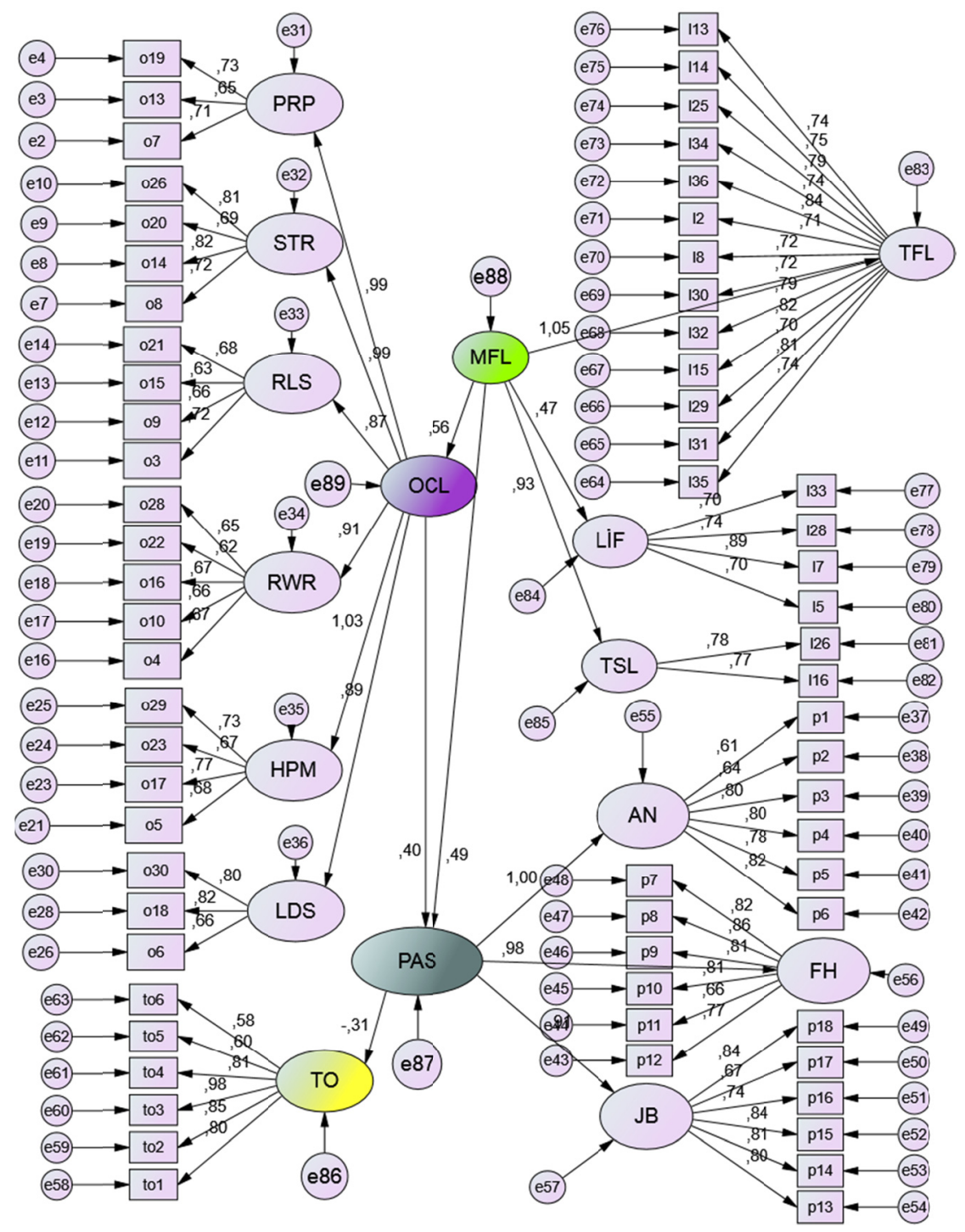

Figure 5. The Path analysis of the projected model

The model was within the acceptable limits as the result of the model analysis was $\mathrm{x} 2 / \mathrm{df}(1.720)$. The goodness-of-fit indices of the model were found as RMSEA $=0.054, \mathrm{GFI}=0.859, \mathrm{CFI}=0.955$ and $\mathrm{SRMR}=0.0743$. These values indicate that the research model is within the acceptable limits.

The findings from the model are presented in Table 3.

Table 3. Regression and determination coefficients

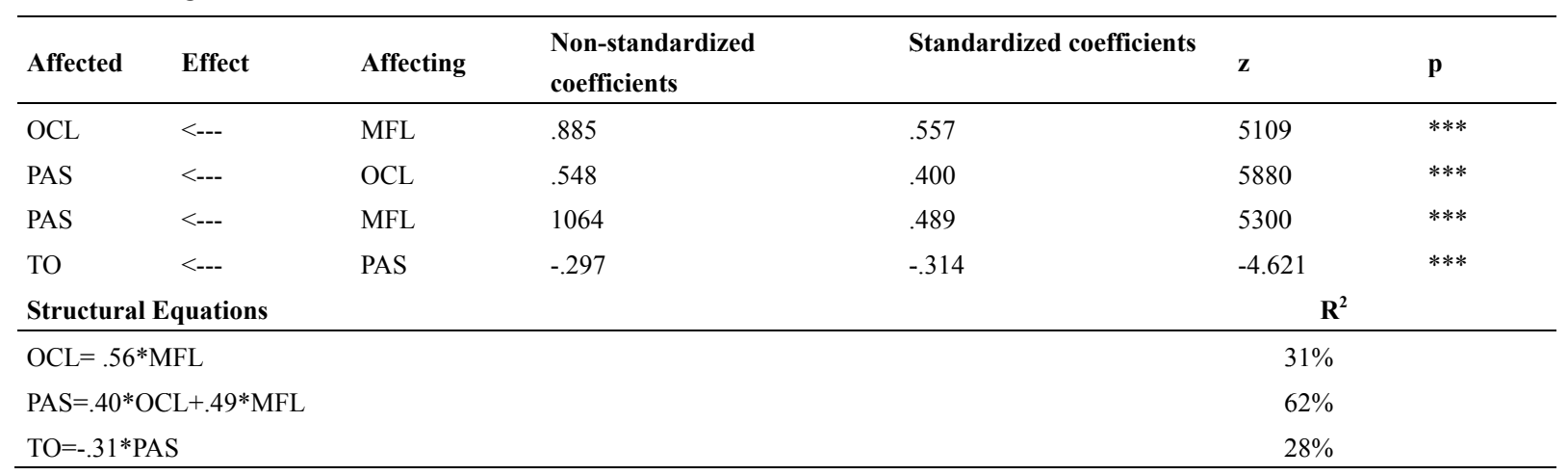


According to the structural equation results obtained from the model, organizational diagnosis is positively affected by leadership style and explained by $31 \%$. According to the second structural equation, performance appraisal satisfaction is positively affected by organizational diagnosis (.40) and leadership style (.49), and explained by $62 \%$. According to the last structural equation, the implicit variable turnover intention is negatively affected by the implicit variable performance appraisal satisfaction (-.31) and explained by $28 \%$.

\section{Discussion, Implications and Limitations}

The present study explored the relationships between perceived leadership style, organizational diagnosis, performance appraisal satisfaction, and turnover intention. The results affirmed all study hypotheses, demonstrating that leadership style is positively related to organizational diagnosis and performance appraisal satisfaction, while organizational diagnosis has a positive impact on performance appraisal satisfaction. Furthermore, turnover intention is negatively affected by performance appraisal satisfaction. We believe that this study advances the available literature on organizational management by revealing the extent to which employee attitudes are affected by the perceived leadership style and the importance of diagnosing organizational issues for employee satisfaction with performance appraisal systems.

Our study results explicitly indicate that the style of leadership as perceived by employees is of great importance for organizations. Although there has been a vast amount of research on leadership, its influence on performance appraisal satisfaction is scarce to the best of our knowledge. Performance appraisal has recently acquired a critical place as a human resources practice and though it focused on maintenance and control before, it has now turned into a more constructive concept that involves development, motivation and improvement (Obisi, 2011).

Based on our study findings, transformational leadership, which is especially associated with motivation and inspiration, is likely to enhance the degree to which employees are satisfied with their performance appraisal process. This result is in agreement with the study by Tuytens and Devons (2012) that reported the impact of leadership characteristics on the employee reactions to appraisal. In light of such findings, we recommend organizations to promote transformational leadership style in order to enhance the appraisal satisfaction levels of their employees because satisfaction with appraisal system is likely to depend on the appraiser. Additionally, organizations may also develop a performance appraisal system that suits the unique characteristics of the organization as well as considering the expectations of employees. This kind of an appraisal system should also enable leaders and employees to have an open discussion regarding expectations and accomplishments, taking account of employees' development and performance in the future. By this way, employees will be able to express their opinions and feelings about the appraisal system and potential issues can be prevented before adverse outcomes. We believe that this will also reduce employees' intentions to quit their jobs since a quality practice of performance appraisal with an open communication channel results in greater motivation and better performance (Zimmerman, 2009). As a result, employees who are satisfied with the appraisal system will want to keep their employment (Benson et al., 2010), leading to a low rate of turnover.

The style of leadership also has influence on organizational diagnosis, as confirmed by the second hypothesis of this study. This is an expected outcome because leadership is one of the categories in the six-box model introduced by Weisbord (1976) to identify internal problems within an organization. According to this model, leaders have to define clear purposes and act accordingly. In this sense, transformational leaders are known to set clear goals and a clear vision, which may be considered suggestive of an impact on the organizational diagnosis system. As diagnosing issues within an organization brings changes, transformational leaders may serve as a key actor in such process. Therefore, we suggest that organizations should check the effectiveness of their leaders and provide trainings or support when necessary. This would improve the diagnosis process and thereby, facilitate organizational changes.

As affirmed by our third hypothesis, diagnosing organizational issues creates a positive effect on employees' satisfaction with the performance appraisal system. By using the six-box model (Weisbord, 1976), organizations can better understand their problems and achieve a balance between their formal and informal systems. Since, among others, this model specifically emphasizes purpose (mission) as it shapes employees' perceptions and attitudes about the organization, we recommend organizations to formulate and elucidate a clear mission. We believe that transformational leaders would provide additional contribution to this purpose based on our second finding.

The last finding of this study demonstrated a negative relationship between performance appraisal satisfaction and turnover intention. This is in line with the study by Kadiresan et al. (2015) that established a positive correlation between performance appraisal and commitment, which leads to lower turnover. Therefore, we suggest that organizations should determine the factors underlying employees' unsatisfaction with the 
performance appraisal system in order to reduce their turnover intentions.

Despite its contributions, our study is not without limitation. The sample size of this study may pose a challenge for generalizability. Future research with a broader sample would produce better results, especially if it includes different business fields. By this way, the impact of different organizational concepts on both the leadership perception and organizational change can be examined. Furthermore, we believe that the link between performance appraisal perception, turnover intention and career commitment is worth investigating in terms of revealing the individual factors. Additionally, the effect of organizational change on turnover intention can be explored using performance appraisal satisfaction as a mediator. This would help organizations to adopt effective human resources practices in order to avoid losing talented employees. Finally, future studies may examine the relationships between the subdimensions of the variables in the present study in order to reach a detailed conclusion.

\section{References}

Abbasi, S. M., \& Hollman, K. W. (2000). Turnover: The real bottom line. Public Personnel Management, 29, 333-342. https://doi.org/10.1177/009102600002900303

Arshadi, N., \& Shahbazi, F. (2013). Workplace characteristics and turnover intention: Mediating role of emotional exhaustion. Procedia-Social and Behavioral Sciences, 84, 640-645. https://doi.org/10.1016/j.sbspro.2013.06.618

Avolio, B. J., Bass, B. M., \& Jung, D. I. (1999). Re-examining the components of transformational and transactional leadership using the Multifactor Leadership Questionnaire. Journal of Occupational and Organizational Psychology, 72, 441-462. https://doi.org/10.1348/096317999166789

Bacal, R. (2004). Manager's guide to performance reviews. New York: McGraw-Hill.

Bass, B. M. (1985). Leadership and performance beyond expectations. Free Press, New York.

Bass, B. M., \& Avolio, B. J. (1997). Full range leadership development: Manual for the multifactor leadership questionnaire. CA, Mind Garden.

Bass, B., \& Riggio, R. E. (2006). Transformational leadership (2nd ed.). Mahwah, NJ: Lawrence Erlbaum.

Benson, J., Brown, M., \& Hyatt, D. (2010). Consequences of the performance appraisal experience. Personnel Review, 39(3), 375-396. https://doi.org/10.1108/00483481011030557

Boachie-Mensah, F.O. \&Seido, P.A. (2012). Employees' perception of performance appraisal system: a case study, employees' perception of performance appraisal system: A case study. International Journal of Business and Management, 7(2), 73-88. https://doi.org/10.5539/ijbm.v7n2p73

Bono, J. E., \& Judge, T. A. (2003). Self-concordance at work: Toward understanding the motivational effects of transformational leaders. Academy of Management Journal, 46, 554-571. https://doi.org/10.2307/30040649

Boswell, W.R., \& Boudreau, J.W. (2002). Separating the developmental and evaluative performance appraisal uses. Journal of Business and Psychology, 16, 391-412. https://doi.org/10.1023/A:1012872907525

Brown, M. \& Benson, J. (2005) Managing to overload? Work overload and performance appraisal processes. Group \& Organization Management, 30(1), 99- 124. https://doi.org/10.1177/1059601104269117

Buehler, L.M. (2006). Due process dimensions of performance appraisal, perceptions of organizational justice and some outcomes (Doctor of Philosophy). DePaul University Department of Psychology College of Liberal Arts and Sciences, Chicago.

Burns, J. M. (1978). Leadership. Harper \& Row Publishers, New York.

Cennamo, L., \& Gardner, D. (2008). Generational differences in work values, outcomes and person-organisation values fit. Journal of Managerial Psychology, 23(8), 891-906. https://doi.org/10.1108/02683940810904385

Cummings, T. G. (2005). Organization development and change (8th edition). Ohio: South Western Thompson.

Deal, T., \& Kennedy, A. (2000). Corporate cultures, the rites and rituals of corporate life. Cambridge, MA: Perseus Publishing.

Dusterhoff, C., Cunningham, J. B., \& MacGregor, J. N. (2014). The effects of performance rating, leader-member exchange, perceived utility, and organizational justice on performance appraisal satisfaction: Applying a moral judgment perspective. Journal of Business Ethics, 119, 265-273. https://doi.org/10.1007/s10551-013-1634-1 
Folger, R., Konovsky, M. A., \& Cropanzano, R. (1992). A Due process metaphor for performance appraisal. Research in Organizational Behaviour, 14, 129-177.

French, W. L., Bell, C.H., \& Vohra, V. (2006). Organization development. New Delhi: Pearson Education, Inc.

Giles, W. F., \& Mossholder, K. W. (1990). Employee reactions to contextual and session components of $\begin{array}{llllll}\text { performance appraisal. Journal of Applied Psychology, } & 75, \quad 371-\end{array}$ https://doi.org/10.1037/0021-9010.75.4.371

Griffeth, R. W., Hom, P. W., \& Gaertner, S. (2000). A meta-analysis of antecedents and correlates of employee turnover: Update, moderator tests, and research implications for the Next Millennium. Journal of Management, 26, 463-488. https://doi.org/10.1177/014920630002600305

Harris, K. J., Kacmar, K. M., \& Witt, L. A. (2005). An examination of the curvilinear relationship between leader-member exchange and intent to turnover. Journal of Organizational Behavior, 26, 363-378. https://doi.org/10.1002/job.314

Hughes, L. W., Avey, J. B., \& Nixon, D. R. (2010). Relationships between leadership and followers' quitting intentions and job search behaviors. Journal of Leadership \& Organizational Studies, 17, 351-362. https://doi.org/10.1177/1548051809358698

Huselid, M. A. (1995). The impact of human resource management practices on turnover, productivity and corporate financial performance. Academy of Management Journal, 38, 635-72. https://doi.org/10.2307/256741

Judge, T. A., \& Piccolo, R. F. (2004).Transformational and transactional leadership: A meta-analytic test of their relative validity. Journal of Applied Psychology, 89(5), 755-768. https://doi.org/10.1037/0021-9010.89.5.755

Kadiresan, V., Selamat, M.H., Selladurai, S., SPR, C.R. and Mohammed, R.K.M.H. (2015). Performance appraisal and training and development of human resource management practices (HRM) on organizational commitment and turnover intention. Asian Social Science, 11(24), 162-176. https://doi.org/10.5539/ass.v11n24p162

Keeping, L.M., \& Levy, P.E. (2000). Performance appraisal reactions: Measurement, modeling, and method bias. Journal of Applied Psychology, 85(5), 708-723. https://doi.org/10.1037/0021-9010.85.5.708

Kimiz, D. (2005). Knowledge management in theory and practice. Oxford, UK: Elsevier Inc..

Kozioł, L., Kozioł, W., Wojtowicz, A., \& Pyrek, R. (2015). Diagnosis of innovation enterprises-Study theoretical and empirical results. Procedia - Social and Behavioral Sciences, 175, 137-145. https://doi.org/10.1016/j.sbspro.2015.01.1184

Kuvaas, B. (2011). The interactive role of performance appraisal reactions and regular feedback. Journal of Managerial Psychology, 26(2), 123-137. https://doi.org/10.1108/02683941111102164

Limsila, K., \& Ogunlana, S. O. (2008). Performance and leadership outcome correlates of leadership style and subordinate commitment. Engineering, Construction and Architectural Management, 15(2), 164-184. https://doi.org/10.1108/09699980810852682

Moynihan, D. P., \& Landuyt, N. (2008). Explaining turnover intention in state government: Examining the roles of gender, life cycle, and loyalty. Review of Public Personnel Administration, 28, 120-143. https://doi.org/10.1177/0734371X08315771

Nielsen, K., \& Munir, F. (2009). How do transformational leaders influence followers' affective wellbeing? Exploring the mediating role of self-efficacy. Work \& Stress, 23, 313-329. https://doi.org/10.1080/02678370903385106

Oberfield, Z. W. (2014). Public management in time: A longitudinal examination of the full range of leadership theory. Journal of Public Administration Research and Theory, 24, 407-429. https://doi.org/10.1093/jopart/mus060

Obisi, C. (2011). Employee performance appraisal and its implication for individual and organizational growth. Australian Journal of Business and Management Research, 1(9), 92-97.

Paarlberg, L. E., \& Lavigna, B. (2010). Transformational leadership and public service motivation: Driving individual and organizational performance. Public Administration Review, 70, 710-718. https://doi.org/10.1111/j.1540-6210.2010.02199.x 
Pieterse, A. N., Knippenberg, D. V., Schippers, M., \& Stam, D. (2010). Transformational and transactional leadership and innovative behavior: The moderating role of psychological empowerment. Journal of Organizational Behavior, 31, 609-623. https://doi.org/10.1002/job.650

Price, J.L. (1977). The study of turnover (1st ed.). IOWA: State University Press.

Rainey, H. G. (2009). Understanding and managing public organizations (4th ed.). San Francisco, CA: Jossey-Bass.

Sarita, K. (2012). A study on performance appraisal errors of telecom managers in Navi Mumbai region. SIES Journal of Management, 8(2), 3-13.

Schermelleh-Engel, K., Moosbrugger, H., \& Müller, H. (2003). Evaluating the fit of structural equation models. Methods of Psychological Research, 8(2), 23-74.

Schyns, B., Torka, N., \& Gossling, T. (2007). Turnover intention and preparedness for change: Exploring leader-member exchange and occupational self-efficacy as antecedents of two employability predictors. Career Development International, 12(7), 660-679. https://doi.org/10.1108/13620430710834413

Schwepker, C. (2001). Ethical climate's relationship to job satisfaction, organizational commitment and turnover intention in the salesforce. Journal of Business Research, 54, 39-52. https://doi.org/10.1016/S0148-2963(00)00125-9

Srithongrung, A. (2011). The causal relationships among transformational leadership, organizational commitment, and employee effectiveness. International Journal of Public Administration, 34, 376-388. https://doi.org/10.1080/01900692.2011.569917

Tuytens, M., \& Devos, G. (2012). Importance of system and leadership in performance appraisal. Personnel Review, 41(6). https://doi.org/10.1108/00483481211263692

Vigoda, E. (2003). Developments in organizational politics. Cheltenham: MPG Books Ltd.

Watrous, K. M., Huffman, A. H., \& Pritchard, R. D. (2006). When coworkers and managers quit: The effects of turnover and shared values on performance. Journal of Business and Psychology, 21, 103-126. https://doi.org/10.1007/s10869-005-9021-2

Weisbord, M. B. (1976). Organizational diagnosis: Six places to look for trouble with or without a theory. Group \& Organization Studies, 1(4), 430-447. https://doi.org/10.1177/105960117600100405

Yukl, G. A. (2002). Leadership in organizations (5th ed.). Upper Saddle River, NJ: Prentice Hall.

Zimmerman, K. (2009). The impact of job performance on employee turnover and the voluntary turnover process: A meta-analysis and path model. Personnel Review, 38(2), 142-158. https://doi.org/10.1108/00483480910931316

\section{Copyrights}

Copyright for this article is retained by the author(s), with first publication rights granted to the journal.

This is an open-access article distributed under the terms and conditions of the Creative Commons Attribution license (http://creativecommons.org/licenses/by/4.0/). 